\title{
A Note on the Efficiency Effects of Agglomeration Economies: Turkish Evidence
}

\author{
K. Peren Arin ${ }^{1,2, \#}$, Tolga Omay ${ }^{3, \#}$ and Deniz Timurçin ${ }^{4, *}$ \\ ${ }^{1}$ Zayed University, Abu Dhabi, UAE; ${ }^{2}$ CAMA, Canberra, Australia; ${ }^{3}$ Cankaya University, Cankaya University, \\ Ankara, Turkey; ${ }^{4}$ KOSGEB Ankara, Turkey
}

\begin{abstract}
By using a very novel dataset from Turkish SMEs, this paper investigates the effects of agglomeration economies on productive and allocative efficiency. After controlling for unobserved heterogeneity at the time level, our empirical results from ordered panel probit models provide evidence that clusters have no statistically significant effect on productive efficiency but a negative effect on allocative efficiency. We also show that the increase in prices is not due to increased product differentiation; therefore, it is most likely due to collusion.
\end{abstract}

Keywords: SMEs, Cluster, Competitiveness, Productive and Allocative Efficiency, Ordered Panel Probit Models.

\section{INTRODUCTION}

Since the seminal work by Porter (1990), academic interest in clusters has been vast. Porter (1998) argues that, in the past, competition was heavily driven by input costs, and therefore location was a factor that could create a comparative advantage for the firm. Today, on the other hand, in an environment of dynamic competition which includes global markets, comparative advantage can only be obtained by more efficient use of inputs, which requires innovation. As external environment is of crucial importance for innovation, many companies choose to be within clusters. Prescott (1998) also points out that it is very difficult to explain international income differences without controlling for the diversity of local conditions fostering or deterring the adoption of new technologies.

As Belleflamme et al. (2000) contend that, it is a well-established fact in urban economics that firms belonging to the same sector benefit from an increase in "productive efficiency" when they locate together. We should also note that while a large number of studies have documented the positive externalities stemming from agglomeration economies (Chung and Kalnins; 2001, for instance), there does not seem to be a consensus regarding the effects of clusters on competition, or "allocative efficiency". While one might expect increased price competition (consumers can more easily compare prices) and a decline in rents through geographical proximity, firms in the cluster might prevent competition through collusion (Labrecciosa and Colombo; 2010) or through product differentiation (Belleflamme et al. 2000).

*Address correspondence to this author at the KOSGEB Ostim HMM, Cevat Dündar Cad. No: 156, 06370 Ostim/Yenimahalle, Ankara, Turkey; Tel: +90 312 59284 34; E-mail: deniz.timurcin@kosgeb.gov.tr

\#Co-Author E-mails: z9158@zu.ac.ae, omayt@cankaya.edu.tr

Jel Classifications: D21, C23, C24.
In this paper, we empirically test the effects of clusters on productive and allocative efficiency by using a novel dataset that includes 155 Turkish firms from different industries regarding the 2005-2009 periods. The panel nature of our dataset allows us to control for unobserved heterogeneity. Our empirical results from ordered panel probit models provide evidence that clusters have no statistically significant effect on productive efficiency but a negative effect on allocative efficiency. We also show that the increase in prices is not due to increased product differentiation, therefore, the increase in prices is most likely due to collusion.

The remainder of this paper is organized as follows: Section 2 discusses the dataset and the empirical, methodology used, section 3 presents the empirical results and section 4 concludes.

\section{DATA AND METHODOLOGY}

Our dataset is obtained from sending a survey to 155 firms all operating in OSTIM Industrialized Zone, Ankara, Turkey. 54 of these 155 firms are part of 4 different industrial clusters, while 101 of them are not part of a cluster. All 155 firms are chosen via random sampling ${ }^{1}$. The survey asked firms to self-report their costs, prices, product differentiation, and production alongside other variables of interest as a structured scale. Table 1 presents the definitions for all model variables, while Table 2 presents summary statistics.

The empirical model estimated is as follows:

${ }^{1}$ Initially 500 firms were chosen in 2010 via Random sampling from the OSTIM industrial area, and a survey was sent to all firms. A pilot study revealed that firms are not willing to "reveal" their production, cost and price data, and therefore, the firms were asked to report those variables on a scale. Only 70 firms completed the online survey. The remainder of the firms were contacted for a second time, and 85 additional firms accepted face-to-face interviews. 
Table 1: Variable Definitions

\begin{tabular}{|c|c|}
\hline Variable & Explanation \\
\hline \hline & Productive Efficiency Variables \\
\hline Production & Self-Reported Production (Likert Scale) \\
\hline Cost & Self-Reported Costs (Likert Scale) \\
\hline & Allocative Efficiency Variables \\
\hline Price & Self-Reported Prices (Likert Scale) \\
\hline Product Diff. & Self-Reported Prod. Diff. (Likert Scale) \\
\hline
\end{tabular}

Table 2: Summary Statistics

\begin{tabular}{|c|c|c|c|c|}
\hline Variable & Obs & Mean & Std. Dev. & Min \\
\hline \hline Price & 775 & 1.903 & 0.743 & 1 \\
\hline Cost & 775 & 1.374 & 0.654 & 0.373 \\
\hline Product Differentiation & 775 & 1.167 & 0.604 & 1 \\
\hline Production & 775 & 1.335 & 3 \\
\hline
\end{tabular}

$$
E_{i t}=\alpha_{0}+\alpha_{1} C D+\alpha_{2} I+\epsilon_{i t}
$$

Where $E$ is the efficiency variable of interest, $C D$ is the cluster dummy which takes the value of 1 if the firm $i$ is located in a cluster (agglomeration economy), I is the vector of year dummies to control for unobserved heterogeneity at the time level and $\epsilon_{i t}$ is the normally distributed error term. We should also note that full convergence is not achieved when firm and/or industry dummies are included in the estimations.

\section{EMPIRICAL RESULTS}

\subsection{Benchmark Model}

The empirical results for productive efficiency variables are presented in Table 3. Our empirical results suggest that being in an agglomeration economy had no statistically significant effect on any of the productive efficiency variables. This result is quite surprising and contradicts with the previous literature reporting efficiency gains from geographical proximity. Coulibaly et al. (2007) argue that, while the new economic geography literature suggest firms located in an agglomerated area can take advantage from a larger market and the proximity of intermediate products' suppliers (localization and urbanization effects), this positive externality can be counterbalanced by high congestion costs and increased competition. Thus, it becomes really imperative to look at what happens to allocative efficiency.

Table 4 presents the empirical results of regressions that investigate the effects of agglomeration economies on allocative efficiency. Our results suggest that agglomeration economies had a significant positive effect on prices (Regression 3),

Table 3: Effects of Agglomeration Economies on Productive Efficiency

\begin{tabular}{|c|c|c|}
\hline & Dependent Variable: Cost & Dependent Variable: Production \\
& (1) & $0.0123(0.13)$ \\
\hline \hline Cluster dummy & $-0.008(-0.08)$ & Yes \\
\hline Year Dummies? & Yes & - \\
\hline Constant & - & 0.02 \\
\hline Chi_Sq & 0.01 & 0.0000 \\
\hline Psuedo $R^{2}$ & 0.0000 & 775 \\
\hline Nobs & 775 & Ordered Probit \\
\hline
\end{tabular}


Table 4: Effects of Agglomeration Economies on Allocative Efficiency

\begin{tabular}{|c|c|c|}
\hline & Dependent Variable: Price & Dependent Variable: Product Differentiation \\
(4)
\end{tabular}

Note: * denotes the significance level at $1 \%$ percent.

while they had a significant negative effect on product differentiation (Regression 4). Hence, we cannot explain the increase in prices with an increase in the product differentiation. It is most likely that the agglomeration economies, when they are unregulated, like they were in Turkey, encourage firms for tacit collusion, which leads to a decline in the allocative efficiency despite standardization of products.

\subsection{Robustness Checks}

The empirical results by using bootstrap methodwhich attempts to remedy our relatively small sample size- are presented in Table 5. Our empirical results remain essentially the same. Neither of the productive efficiency variables, consistent with our previous results, are significantly affected by the cluster dummy. In terms allocative efficiency, firms' perceived prices rise while products are more standardized- pointing, once again, to collusion between firms.

As the cluster dummy might have a statistically significant effect on both productive and allocative efficiency simultaneously, we present Seemingly Unrelated Regression (SUR) estimation in Table $\mathbf{6}$ as a robustness check. Similar to our bootstrapping exercise, our results remain essentially the same.

Table 5: Effects of Agglomeration Economies-Bootstrap Estimation

\begin{tabular}{|c|c|c|c|c|}
\hline Dependent Variable & Cost & Production & Price & Product Differentiation \\
\hline \hline Cluster dummy & $-0.08(-0.07)$ & $0.012(0.14)$ & $0.264^{*}(3.00)$ & $-0.372^{*}(-3.26)$ \\
\hline Year Dummies? & Yes & Yes & Yes & - \\
\hline Constant & - & - & - & $10.61^{*}$ \\
\hline Chi_Sq & 0.01 & 0.02 & 0.01 & 0.01 \\
\hline Psuedo $R^{2}$ & 0.00 & 0.00 & Ordered Probit with Bootstrap \\
\hline Estimation Method & \multicolumn{2}{|c|}{} \\
\hline
\end{tabular}

Note 1: * denotes the significance level at $1 \%$ percent.

Note 2: We apply the bootstrap method to obtain critical values of the test statistics. To this end, we report p-values by using 500 bootstrap repetitions.

Table 6: Effects of Agglomeration Economies-SUR Estimation

\begin{tabular}{|c|c|c|c|c|}
\hline Dependent Variable & Cost & Production & Price & Product Differentiation \\
\hline \hline Cluster dummy & $-0.06(-0.12)$ & $-0.03(-0.07)$ & $0.177^{*}(3.18)$ & $-0.087^{*}(-3.10)$ \\
\hline Year Dummies? & Yes & Yes & Yes & Yes \\
\hline Constant & $1.376^{*}(33.73)$ & $1.337^{*}(35.36)$ & $1.842^{*}(39.87)$ & $1.198^{*}(51.56)$ \\
\hline Psuedo $R^{2}$ & 0.0000 & 0.0000 & 0.0129 & 0.0123 \\
\hline Estimation Method & \multicolumn{2}{|c|}{ SUR } \\
\hline
\end{tabular}

Note 1: * denotes the significance level at $1 \%$ percent. 


\section{CONCLUSION}

The theoretical and empirical urban economics literature is full of praise of agglomeration economies, or, industrial clusters. By using a novel data set from Turkey, we empirically test the hypothesized effects of clusters on productive and allocative efficiency. Our results fail to provide evidence in favour of aforementioned positive productive efficiency gains. Rather, we find that firms tend to standardize their products and possibly collude on prices. These results are quite different than those of Coulibaly et al. (2007) who documents a positive effect of urbanization on productivity, also by using Turkish data. However, in our study, we look at both allocative and productive efficiency and we not only fail to document positive productive efficiency gains, but also we provide some negative effects on allocative efficiency. Our results do not suggest that agglomeration economies are harmful, rather they point out that they might need to be regulated. Further avenues of research certainly include empirically investigating the effects of clusters in other countries.

\section{REFERENCES}

Belleflamme P., Picard, P. and J. F. Thisse (2000), "An Economic Theory of Regional Clusters", Journal of Urban Economics 48 (1), 158-184. http://dx.doi.org/10.1006/juec.1999.2161

Chung W. and A. Kalnins (2001), "Agglomeration Effects and Performance: A test of The Texas Lodging Industry", Strategic Management Journal 22, 969-988. http://dx.doi.org/10.1002/smj.178

Coulibaly, S., Deichmann, U. and S. Lall (2007), "Urbanization and Productivity: Evidence from Turkish Provinces 1980-2000., World Bank Poicy Research Paper 4387.

Labrecciosa P. and L. Colombo (2010), "Technology Uncertainty and Market Collusion", The Berkeley Electronic Journal of Economic analysis \& policy 10 (1), 1-15.

Porter, M. (1990), "The competitive advantage of nations", The Free Press: New York, 127-130.

Porter M. (1998), "Clusters and The New Economics of Competition", Harvard Business Review; Boston; Nov/Dec 76(6), 77-90.

Prescott E. C. (1998), "Nedded: A theory of Total Factor Productivity", International Economic Review 39, 525-551. http://dx.doi.org/10.2307/2527389

(c) 2014 Arin et al.; Licensee Lifescience Global.

This is an open access article licensed under the terms of the Creative Commons Attribution Non-Commercial License (http://creativecommons.org/licenses/by-nc/3.0/) which permits unrestricted, non-commercial use, distribution and reproduction in any medium, provided the work is properly cited. 